is a representative of the Lycopodiales associated with a diversified taphoflora composed of sphenophytes (e.g. Stephanophyllites, Phyllotheca and Paracalamites); protoglossopterids (e.g. Rubidgea and Palaeovittaria); glossopterids (e.g. Gangamopteris); seeds (e.g. Samaropsis and Cornucarpus); proto- and glossopterid fructifications (Arberia, Arberiopsis, Itapemia and Hirsutum-like frutifications). The entire phytofossiliferous assemblage is representative of the earliest development stage of the Glossopteris Paleoflora in the Paraná Basin (AsselianSakmarian).

The Transitional Taphoflora "A-B', of the Paraná Basin or association Rubidgea-Gangamopteris-Arberia of S. Paulo State may correspond to an interglacial or post-glacial stage of warmer climate during which coal seams were formed. This taphoflora is included in a siltstone bed of Tubarão Group, probably at the top of the Itararé Subgroup.

The studied specimen, Lycopodites sp., is a fertile form with sporangia arranged in axils of microphylls spread over through the vegetative body. Despite of not being possible to confirm homospory, due to the preservation state of the specimen, the apparent absence of ligule, the presence of uninervate microphylls and mainly the presence of sporophylls with axilary sporangia similar to vegetative microphylls dispersed among them support its assignment to Lycopodites Lindley et Hutton 1833.

To the present knowledge, this is one of the first occurrences of the Order Lycopodiales, not only in the South American continent, but also in the whole Gondwana. - ( December 14, 2001 ).

\footnotetext{
* Supported by FAPESP 97/03639-8.

**E-mail: fcbranco@cwaynet.com.br or fresia@ige.unicamp.br ***E-mail: maryeliz@usp.br
}

\section{CONTAMINATION POTENTIAL OF THE ILHABELA (SP) LANDFILL}

Cristiane L. Rodrigues and Fabio Taioli

Instituto de Geociências / USP, 05508-900 São Paulo, SP.

Presented by Antonio C. Rocha-Campos

Ilhabela is a city in the São Paulo northern seashore located about $220 \mathrm{~km}$ from the capital of the state. Its geographical position is determined by the parallels $23^{\circ} 42^{\prime}$ and $23^{\circ} 56^{\prime} \mathrm{S}$ and the meridians $45^{\circ} 41^{\prime}$ and $45^{\circ} 28^{\prime} \mathrm{W}$ and altitude varying from the sea level up to $1300 \mathrm{~m}$. The economic basis of the city are the tourism and fishing and it is known as "Sailing Capital" (Capital da Vela) due to the optimum conditions to practice of that nautical sport. About $83 \%$ of Ilhabela's area are in the State Park (preservation area created on January 20, 1977 by Decree 9414). Its population is about 13,500 inhabitants, raising up to 150,000 during the summer season. The research area is located about $5 \mathrm{~km}$ from downtown Ilhabela and can be reached by the road SP 131. Previous studies pointed out that due to local land use restrictions there is no other appropriate site for the sanitary landfill. The landfill is in operation since 1987 and receives the domestic and construction solid wastes and tree trimmings generated in the county. The material is disposed on the soil and mixed with soil of the same region taken from a neighbor area. It is located in a neighborhood close to a fundamental school and several houses, and with no foundation treatment and no control of the leachate destination. Due to the high contamination potential of the leachate generated in such type of waste disposition, it may contaminate the soil, changing its physical, chemical and biological characteristics and compromising the water of rivers and groundwater by modification of its natural characteristics. This paper intends to investigate the potential of contamination of the landfill. Soil, groundwater and surface water samples were taken and chemical and physicchemical analyses were carried out. The results suggest that the heavy metals that are carried by the leachate remain mainly associated to the soil, but may be diluted and reach the groundwater under special conditions, e.g. acid rain. In addition, the leachate is compromising the groundwater quality since chemical analyses show that other ions have already reached it. - ( December 14, 2001 ).

\section{SUBDUCTED CONTINENTAL CRUST: METAMORPHIC CONTROL OF DECOMPRESSION IN THE HIND POR- TION OF THE AIURUOCA-ANDRELÂNDIA NAPPE, SOUTH-SOUTHWEST BORDER OF SÃO FRANCISCO CRATON, MINAS GERAIS* \\ Luciana P. Santos and Mario C. Campos Neto \\ Instituto de Geociências, USP, São Paulo, SP. \\ Presented by ANTONIO C. Rocha-CAmpos}

The Nappe system in south-southwest São Francisco Craton represents the southern extension of the Brazilian belt and describes an inverted metamorphic pile (stack) of green schist facies (bottom) toward amphibolite facies (Carmo da Cachoeira e Aiuruoca-Andrelândia nappes) and high pressure granulites in the top, under a high tem- 
perature allochtonous (Socorro-Guaxupé nappe).

The hind portion of the Aiuruoca-Andrelândia nappe, south of Caxambú and Aiuruoca (MG), consists of a structural-metamorphic domain with extensional structures in normal shear zones and compressive structures exhibiting E-NE transport. Tourmaline leucogranites in stratiform bodies and diatexitic gneisses occur frequently. There is a metamorphic transition, north to south, from the kyanite zone (and metabasic rocks in eclogite facies) to kyanite and sillimanite coexistence, until kyanite broken and exclusive sillimanite presence.

The $S_{2}$ texture foliation on mineral assemblage, suggests a decompressive path, where metabasics boudins preserve paragenese eclogite facies (Omp-Pl-Grt-Rt-Qtz) with simplectite textures between Cpx-Pl-Qtz. Externally, corroded garnets wrapped by plagioclase coronas, in amphibole matrix, represent the amphibolite facies reequilibration (MgHbl-Pl-Grt-Zo-Ilm-Ttn). Metapelites (RtKy-Grt-Ms-Bt-Pl-Qtz) may show Sil-Pl-Qtz coronitic intergrowths around garnets.

The maximum temperatures for the distinguished metamorphic domains (14 samples), vary from $710 \pm$ $30^{\circ} \mathrm{C}$ (Ky domain) to $730 \pm 50^{\circ} \mathrm{C}$ (Sil domain). Although the pression vary at $17 \pm 0.5$ to $6 \pm 0.5 \mathrm{kbar}$. P-T conditions at $720 \pm 50^{\circ} \mathrm{C}$ and $11.5 \pm 2.5 \mathrm{kbar}$ marks the kyanite assemblage re-equilibration (amphibole facies). $\mathrm{P}$-T conditions $625 \pm 55^{\circ} \mathrm{C}$ and $6.8 \pm 2 \mathrm{kbar}$ represent the cooling path (Ky-Sil fields).

The high pression decompressive path suggests an extrusional process, immediately after buried at about $60 \mathrm{~km}$ deep. Fast exhumation, process controlled by convergent events, derived by the São Francisco plate subductions and tectonic erosion take these units, isothermally, to upper levels (20-33 km). Later, the metamorphic path shift toward a near-isobaric cooling though in a slower extrusional process.

P-T path continuity through three metamorphic domains suggests a sin-metamorphic process ( $\mathrm{S}_{2}$ foliation) as a continuous effect $S_{1} \times S_{2}$, without diacronism or ensuing event superposition.

However, large amount of leucogranites denotes a regional thermal event, subsequent and superimposed, responsible for quartz static polygonization in schists/gneisses and for Ms breakdown with microcline crystallization $\left(730^{\circ} \mathrm{C} / 6 \mathrm{kbar}\right)$ in the vicinity of large granite plutons. - ( December 14, 2001 ).

\section{STUDY OF THE RADIOACTIVE DISEQUILIBRIUM OF THE VOLCANIC ROCKS FROM THE TRINDADE IS- LAND (BRAZIL)}

Rosana N. Santos ${ }^{1,2}$ And Leila S. Marques ${ }^{1}$

${ }^{1}$ Instituto de Astronomia, Geofísica e Ciências Atmosféricas, Universidade de São Paulo, 01065-970, São Paulo, SP.

${ }^{2}$ Departamento de Física, Pontifícia Universidade Católica de São Paulo, 01303-050, São Paulo, SP.

Presented by ANTONio C. Rocha-CAmpos

The radiochemical procedures employed for the determination of ${ }^{238} \mathrm{U},{ }^{234} \mathrm{U}$ and ${ }^{230} \mathrm{Th}$ activities in silicates by alpha spectrometry are presented. The best experimental conditions were defined using ${ }^{233} \mathrm{U},{ }^{232} \mathrm{U}$ and ${ }^{229} \mathrm{Th}$ radioactive tracers and simulating the usual conditions found in processing silicate samples. The adapted procedure consists of the following steps: radioactive tracer addition and sample dissolution by acid digestion, $U$ and Th pre-concentration by co-precipitation, element separation and purification by ion exchange chromatography and electrodeposition in stainless steel disks. In order to evaluate its effectiveness, the procedure was applied to the Brazilian geological standards BB-1 (basalt) and GB1 (granite). The chemical yields obtained for uranium and thorium are of about $60 \%$ and $70 \%$, respectively, for both matrices. The described methodology provides activity measurements with less than $4 \%$ relative precision and accuracy of about $1 \%$, that are essential for petrogenetic applications.

The ${ }^{238} \mathrm{U}$ and ${ }^{232} \mathrm{Th}$ series disequilibrium conditions were investigated by alpha spectrometry, together with neutron activation analysis and natural gamma-ray spectrometry. ${ }^{234} \mathrm{U} /{ }^{238} \mathrm{U},{ }^{238} \mathrm{U} /{ }^{232} \mathrm{Th}$ and ${ }^{230} \mathrm{Th} /{ }^{232} \mathrm{Th}$ activity ratios were obtained, as well as the ${ }^{234} \mathrm{Th},{ }^{214} \mathrm{~Pb},{ }^{214} \mathrm{Bi}$, ${ }^{235} \mathrm{U},{ }^{228} \mathrm{Ac},{ }^{212} \mathrm{~Pb},{ }^{212} \mathrm{Bi}$ and ${ }^{208} \mathrm{Tl}$ specific activities. These results were interpreted along with additional constraints given by major and minor element concentrations, determined by X-ray fluorescence.

The ${ }^{232} \mathrm{Th}$ series is in secular radioactive equilibrium in all analyzed samples. In the case of the ${ }^{238} \mathrm{U}$ series, the equilibrium condition was verified, as expected, in the oldest rocks from the Trindade Island (Trindade Complex and Desejado Sequence). On the other hand, the results show that, in the samples from the last three volcanic episodes of the island (Morro Vermelho Formation, Valado Formation and Vulcão do Paredão), the ${ }^{230} \mathrm{Th}$ and ${ }^{238} \mathrm{U}$ are not in secular equilibrium. Furthermore, three Morro Vermelho Formation samples analyzed by gamma 